Review Article

\title{
Essential Oils as Antimicrobials
}

Open Access

\author{
Tiffany LaLonde1, Tim Bowser1,2 and Ravi Jadeja1,3* \\ IRobert M. Kerr Food and Ag Products Center, Oklahoma State University, Stillwater, Oklahoma, USA \\ 2 Department of Biosystems and Agricultural Engineering, Oklahoma State University, Stillwater, OK, USA \\ ${ }^{3}$ Department of Animal Science, Oklahoma State University, Stillwater, OK, USA
}

\section{Article Info}

\author{
*Corresponding author: \\ Ravi Jadeja \\ Assistant Professor and Food Safety \\ Specialist \\ 106 FAPC \\ Robert M. Kerr Food \& Ag Products \\ Center \\ Oklahoma State University \\ Stillwater, OK, 74078 \\ USA \\ Tel: 405-744-3922 \\ E-mail: Ravi.Jadeja@okstate.edu
}

Received: January 31, 2019

Accepted: February 15, 2019

Published: February 27, 2019

Citation: LaLonde T, Bowser T, Jadeja R. Essential Oils as Antimicrobials. Madridge J Food Technol. 2019; 4(1): 163-169. doi: $10.18689 / \mathrm{mjft}-1000125$

Copyright: (c) 2019 The Author(s). This work is licensed under a Creative Commons Attribution 4.0 International License, which permits unrestricted use, distribution, and reproduction in any medium, provided the original work is properly cited.

Published by Madridge Publishers

\begin{abstract}
This paper is a review of essential oils and their use in foods, packaging materials and farm animals. Essential oils are aromatic oil liquids obtained from plant materials. They serve crucial roles as antioxidants, pathogen inhibitors and flavoring agents. Because of label appearance concerns, essential oils are increasingly used as food preservatives. Essential oils have a complex composition and properties that vary based on differences in field growth, postharvest and processing conditions. Chemical and physical properties of essential oils affect their ability to act as antimicrobials. The food matrix has a significant impact on the antibacterial properties of essential oils, based on factors like $\mathrm{pH}$, fat and moisture content. Meat products have experienced broad application of essential oils as preservatives, while fish and seafood have seen limited use. Essential oils have been used to clean and preserve vegetables, rice and fruits. Food coatings and packaging materials have been treated with essential oils to enhance food preservation properties. Many factors influence the activity of essential oils in foods including synergism (vacuum packaging, $\mathrm{pH}$, water activity, other preservatives and sodium chloride), antagonism (composition of food and sodium chloride) and additive effects. Many essential oils are regarded as safe, but under certain conditions, they may cause dermatitis and cytotoxicity. Challenges to the expanding use of essential oils as antimicrobials in the food industry include organoleptics, uniformity of composition, and emerging resistance of microbes.
\end{abstract}

Keywords: Essential oil; Antioxidant; Food additive; Preservative.

\section{Introduction}

In recent years, the food industry has seen a major increase in consumer concern and awareness regarding food production and processing. The concern has created a demand for foods that are considered "natural," "all-natural," or "clean label", but also convenient. Satisfying this demand has posed a challenge to food safety because the majority of currently used antimicrobials and preservatives are synthetic and thus not considered "natural" or "clean" by consumers.

Essential oils (EOs) (or volatile/ethereal oils) are aromatic oily liquids obtained from plant materials such as: flowers, buds, seeds, leaves, twigs, bark, herbs, wood, fruits, and roots. They are obtained through expression, fermentation, enfleurage, extraction or steam distillation [1]. Of these methods, steam distillation is most commonly used in commercial production [2]. Paracelsus von Hohenheim, a 16th century Swiss reformer of medicine, is credited with the term 'essential oil.' He used the term Quinta essentia, to describe the effective component of a drug [1].

\section{Overview}

EOs have been used for centuries in medicine, cosmetics, perfumes and added to foods by way of spices and ingredients. It has only been recently that their use as food 
preservatives has been of increasing interest to scientists and consumers. There are approximately 3,000 different essential oils of which 300 are currently utilized commercially in the fragrance and flavor markets [2]. Many EOs are classified as secondary metabolites and possess antimicrobial properties making them important to plants defense [3,4]. In 1881, De la Croix used essential oil vapors to analyze the antibacterial properties of secondary metabolites [5]. Since then EOs, and their components have been found to possess a variety of different functions from broad-range antibacterial properties [8], to functioning as: anti-parasitics, insecticidals, anti-virals, anti-fungals/anti-mycotics, antioxidants/anti-oxigenic and as growth enhancers for animals [6-17]. This paper is a review of... (or other appropriate statement of the purpose of the paper).

\section{Disclaimer}

This paper is not to be used as an all-encompassing source of information regarding EOs and their usage in food production, but only to provide a basic foundation on a variety of topics.

\section{History}

Spices have been used for centuries for their flavor and preservative properties [18]. The earliest mention of EOs was by Greek and Roman historians [1]. Distillation was used to extract and produce EOs more than 2000 years ago by the Egyptians, Persians, and Indians [1]. This process was improved upon by the Arabs in the 9th century [18]. By the 13th century EOs were being made by pharmacies and effects being described in pharmacopoeias [18]. However, their widespread use did not occur until the 16th century, after which they were traded in the City of London [19]. Later in the 16th century, two physicians in Strassburg, publish documents about the distillation and use of EOs (turpentine, juniper wood, rosemary, spike (lavendar), clove, mace, nutmeg, anise and cinnamon) [1]. In the 17th century a French physician, Du Chesne (Quercetanus), mentioned that EOs were widely used and most pharmacies stocked anywhere from 15 to 20 different oils [1]. Australians have been documented using tee tree oil since colonization toward the end of the 18th century, though it is believed that native Australians have been using it long before that [20]. In the 19th and 20th centuries, the use of EOs has shifted from being primarily medicinal to flavor and aroma [1].

Currently EOs are primarily used for flavorings, perfumes and pharmaceuticals $[2,18,21]$. Individual components of EOs are also extracted from plant material or synthetically manufactured for use as food flavorings [22]. These components as well as the EOs themselves have been used extensively as flavor ingredients in varieties of food, beverages and confectionary products, as well as other products such as toothpaste [10]. EOs are also used for aromatherapy, but constitutes a very small portion of the market [2]. EOs have served as antibacterials in products as diverse as dental root canal sealers, antiseptics, and feed supplements [18,23-26].

\section{Processing}

EOs are typically commercially extracted by means of steam distillation and solvent extraction. EOs are sometimes extracted by super critical fluids, like carbon dioxide, but the process is much more expensive [27]. There is a difference in organoleptic profiles between EOs that is obtained by solvent extraction versus steam distillation. This could be a sign of a difference in antimicrobial properties depending on derivation type [28]. EOs are extremely volatile and require dark, airtight storage to slow down compositional changes [5].

\section{Composition}

EOs are composed of both major components and minor components. Compositional analysis of EOs is performed using either gas chromatography or mass spectrometry of the EO or the gas in its saturated headspace [5]. EOs can be comprised of up to sixty individual components, where major components can be up to $85 \%$ and minor components present as trace amounts [29,30]. The composition of EOs from a particular species or plant can vary between harvesting seasons, geographical locations and even different parts of the plant itself [31-33].

Phenolic compounds and their subclasses (coumarins, flavonoids, and EOs) have been shown to have antimicrobial functions [10]. The antimicrobial effects of spices and EOs has been widely accepted $[34,35]$. Some of the major components of EOs that have antibacterial properties are listed in the appendix in table 1 and the structure of a number of antibacterial components are presented in figure 1. EOs that possesses high percentages of phenolic compounds typically has the strongest antibacterial properties against food borne pathogens [5]. Not only do these phenolic compounds act as antimicrobials, but they can also act to inhibit toxin production in food [36].

Table 1. Major Components of selecteda Eos that exhibit antibacterial properties.

\begin{tabular}{|c|c|c|c|c|}
\hline $\begin{array}{l}\text { Common } \\
\text { name of } \\
\text { EO }\end{array}$ & $\begin{array}{l}\text { Latin Name of } \\
\text { Plant Source }\end{array}$ & $\begin{array}{l}\text { Major } \\
\text { Components }\end{array}$ & $\begin{array}{l}\text { Approximate \% } \\
\text { compositionb }\end{array}$ & References \\
\hline Cilantro & $\begin{array}{l}\text { Coriandrum } \\
\text { sativum } \\
\text { (immature } \\
\text { leaves) }\end{array}$ & $\begin{array}{l}\text { Linalool } \\
\text { E-2-decanal }\end{array}$ & $\begin{array}{l}26 \% \\
20 \%\end{array}$ & (Delaquis et al., 2002) \\
\hline Coriander & $\begin{array}{l}\text { Coriandrum } \\
\text { sativum (seeds) }\end{array}$ & $\begin{array}{l}\text { Linalool } \\
\text { E-2-decanal }\end{array}$ & $70 \%$ & (Delaquis et al., 2002) \\
\hline Cinnamon & $\begin{array}{l}\text { Cinnamomum } \\
\text { zeylandicum }\end{array}$ & \begin{tabular}{|l|} 
Trans- \\
cinnamaldehyde
\end{tabular} & $65 \%$ & $\begin{array}{l}\text { (Lens-Lisbonne et al., } \\
\text { 1987) }\end{array}$ \\
\hline Oregano & $\begin{array}{l}\text { Origanum } \\
\text { vulgare }\end{array}$ & $\begin{array}{l}\text { Carvacrol } \\
\text { Thymol } \\
\text { Y-Teripinene } \\
\text { p-Cymene }\end{array}$ & $\begin{array}{l}\text { Trace-80\% } \\
\text { Trace-64\% } \\
2-52 \% \\
\text { Trace-52\% }\end{array}$ & $\begin{array}{l}\text { (Lawrence 1984; } \\
\text { Prudent et al., 1995; } \\
\text { Charai et al., 1996; } \\
\text { Sivrooullou et al., 1996; } \\
\text { Kokkini et al., 1997; } \\
\text { Russo et al., 1998; } \\
\text { Daferera et al., 2000; } \\
\text { Demetzos and } \\
\text { Perdetzoglou, 2001; } \\
\text { Marino et al., 2001) }\end{array}$ \\
\hline Rosemary & $\begin{array}{l}\text { Rosamarinus } \\
\text { officinalis }\end{array}$ & $\begin{array}{l}\alpha \text {-pinene } \\
\text { Bornyl acetate } \\
\text { Camphor } \\
1,8 \text {-cineole }\end{array}$ & $\begin{array}{l}2-25 \% \\
0-17 \% \\
2-14 \% \\
3-89 \%\end{array}$ & $\begin{array}{l}\text { (Daferers et al., 2000, } \\
\text { 2003; Pintore et al., } \\
\text { 2002) }\end{array}$ \\
\hline
\end{tabular}




\begin{tabular}{|c|c|c|c|c|}
\hline Sage & $\begin{array}{l}\text { Salvia } \\
\text { officinalis L. }\end{array}$ & \begin{tabular}{|l|} 
Camphor \\
$\alpha$-pinene \\
$\beta$-pinene \\
1,8 -cineole \\
$\alpha$-tujone
\end{tabular} & \begin{tabular}{|l|}
$6-15 \%$ \\
$4-5 \%$ \\
$2-10 \%$ \\
$6-14 \%$ \\
$20-42 \%$ \\
\end{tabular} & (Marino et al., 2001) \\
\hline $\begin{array}{l}\text { Clove } \\
\text { (bud) }\end{array}$ & $\begin{array}{l}\text { Syzygium } \\
\text { aromaticum }\end{array}$ & $\begin{array}{l}\text { Eugenol } \\
\text { Eugenyl acetate }\end{array}$ & $\begin{array}{l}75-85 \% \\
8-15 \%\end{array}$ & (Bauer et al., 2001) \\
\hline Thyme & \begin{tabular}{|l} 
Thymus \\
vulgaris
\end{tabular} & $\begin{array}{l}\text { Thymol } \\
\text { Carvacrol } \\
\text { Y-Teripinene } \\
\text { p-Cymene }\end{array}$ & $\begin{array}{l}10-64 \% \\
2-11 \% \\
2-31 \% \\
10-56 \%\end{array}$ & $\begin{array}{l}\text { (Lens-Lisbonne et al., } \\
\text { 1987; } \\
\text { McGimpsey et al., } \\
\text { 1994; } \\
\text { Cosentino et al., 1999; } \\
\text { Marino et al., 1999; } \\
\text { Daferera et al., 2000; } \\
\text { Juliano et al., 2000) }\end{array}$ \\
\hline
\end{tabular}

aEos which have been shown to exert antibacterial properties in vitro or in food models and for which the composition could be found in the literature.

bPercentages of total volatiles rounded up to the nearest whole number.
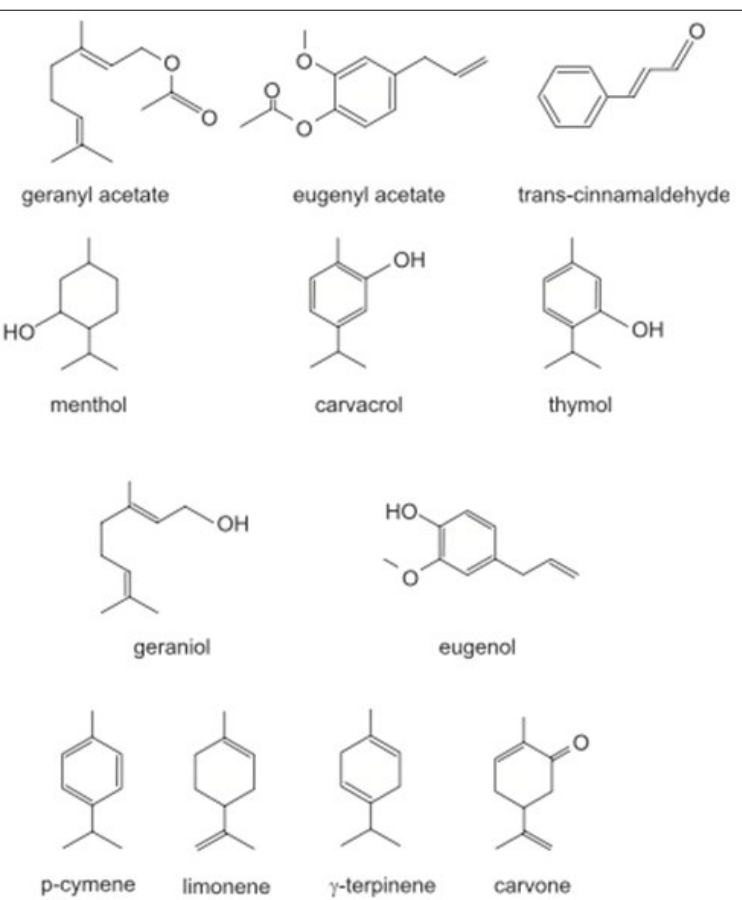

Figure 1. Structural formulae of selected components of EO's.

Both physical and chemical characteristics of EOs can affect their ability to act as antimicrobials. EOs and their components are hydrophobic. This enables them to partition the lipids found in the bacterial cell membranes and mitochondria, thus making the structures more permeable $[37,38]$. The presence of a hydroxyl group in EOs and their components has been shown to greatly affect their ability to function as antimicrobials $[37,39,40]$. EOs can also disrupt the proton motive force, electron flow, active transport and coagulate cell contents [5]. They also can function to impair enzymes and enzyme systems that are integral to regulating and synthesizing structural components [5]. EOs may also inactivate or destroy genetic material, lending to their strength as antimicrobials [41].

\section{Testing}

There is no standard test for antimicrobial measurement of possible preservatives, though the need has been discussed [42]. Due to the lack of standard testing, there is great challenge when attempting to compare the antibacterial properties of different EOs between studies. Different tests use different: amounts of agar, volumes of EOs, usage of solvents, volumes of inoculum, and dilutions of EOs. The minimum inhibitory concentration (MIC) is used by most researchers when reporting antibacterial properties of EOs. However, the definition of MIC varies between studies. Notwithstanding the difference variations, often the MICs of EOs determined by agar solutions appear to be approximate in the order of magnitude [5].

There are a variety of different end point measurement systems, most often optical density (OD) is used. A time-kill analysis (survival curve plot) reports the bactericidal and bacteriostatic effects of EO by plotting the number of viable cells versus time. Scanning electron microscopes (SEM) are used to visualize the damage to cell walls and loss of cell contents. Often great care is taken when preparing samples to limit the differences between preparation methods. This helps to affirm results are strictly due to the effect of the EO [5].

Until the early 1990s, very few studies of the activity of EOs had been published, despite their use by commercial food producers [43]. The antibacterial performance of EOs has been evaluated in studies that utilize in vitro testing; however, it has generally been reported that a greater concentration of EO is needed to achieve the same effect in foods $[34,44]$. While this effect has been mentioned repeatedly, there is little definite explanation as to why this occurs. It has been suggested that both intrinsic and extrinsic properties are the cause to this difference. Intrinsic factors can include attributes such as: fat content, protein content, water content, antioxidants, $\mathrm{pH}$, salt, etc. Extrinsic factors can include: temperature, microorganisms and difference in packaging $[5,34]$.

\section{Food Products}

EOs antibacterial properties function differently between the products they are being used in. If the structure of the food has a gel structure it can greatly reduce the effect of the EO's ability to function as an antibacterial [45]. Due to the colony growth of some bacteria, it has been hypothesized that if the oil droplets are of a certain size, the bacteria within the colonies could be protected from the effects of the EO [5]. In comparing all the published data regarding EOs in food, the approximate ranking (in order of decreasing antibacterial activity) can be made: oregano/clove/coriander/cinnamon> thyme $>$ mint $>$ rosemary $>$ mustard $>$ cilantro/sage [5]. An approximate ranking of EO components is (in order of decreasing antibacterial activity): eugenol $>$ carvacrol/cinnamic acid $>$ basil methyl chavicol>cinnamaldehyde $>$ citral/geraniol [5]. Extracted EOs are often favored over crude spices due to their superior stability during storage, microbial safety, ability to concentrate flavor profiles, reduced storage space requirements, and year round availability [46].

\section{Meat and meat products}

EOs from cinnamon, pimento, oregano, rosemary, thyme, clove, balm, ginger, basilica, coriander, marjoram, fennel, 
savory, and basil have shown great potential as antimicrobial agents in meat and meat products. Cumin, garlic, oregano, and black pepper EOs have all been shown to inhibit the growth of spoilage bacteria $[47,48]$. High fat content has shown to have a limiting (?) effect on the ability of the EO to act as an antimicrobial [5]. Sage has also been shown to have a high inhibitory activity against gram-positive bacteria in meat products [49]. Oregano oil was found to be effective against spoilage microflora when incorporated into meat and meat products [50,51]. E. coli, Salmonella spp., L. monocytogenes, and lactic acid bacteria have all been shown to be affected by different EOs when added to meat and meat products [47].

\section{Fish products}

As in meat products, a high fat content has been shown to reduce the effect of EOs as antibacterials. Oregano oil has been shown to have a high level of effectiveness [52,53]. The spreading of EO on the surface of fish, as well as using EO as a coating on shrimp appear to inhibit natural spoilage flora $[54,55]$.

\section{Dairy products}

Mint oil, cinnamon oil, cardamom oil and clove oils have been found effective against different bacteria when used in dairy products $[52,56]$. Clove, cinnamon, bay and thyme were tested against $L$. monocytogenes and $S$. enteritidis in a soft cheese. The cheese with a higher fat content affected the ability of the oil to act as an antimicrobial. However, clove oil, was more effective in the higher fat cheese against S. enteritidis [57].

\section{Vegetables and Rice}

Since vegetables have a low fat content a variety of EOs has been shown to have significant antimicrobial properties when used in washing water. EOs are more effective when there is a decrease in storage temperature and decrease in $\mathrm{pH}$ [52]. Carvacrol was effective at extending the lag phase and reducing the final population of $B$. Cereus, a prominent bacteria found in rice $[34,58]$.

\section{Fruit}

Adding carvacrol and cinnamaldehyde to a dipping solution was found to reduce the viable count of natural flora present on kiwi, but was less effective on honeydew melon. This is potentially due to the difference in $\mathrm{pH}$ between the two fruits.

\section{Other Applications}

EOs have been not only been used as direct ingredients, which prevent spoilage or growth of bacteria/microorganisms, but also in a variety of other food applications. EOs have been added to edible films and coatings, to slow the growth of pathogenic and spoilage bacteria [47]. EOs have also been applied to storage films and trays for meat products. Incorporation of EOs into the diets of animals destined for slaughter and consumption has also been effective in inhibiting microbial growth after slaughter and processing $[59,60]$.

\section{Influences on activity}

EOs and their components have a variety of effects on each other, other substances used in food production, substances naturally occurring in food products, and preservation methods. Synergism is defined as the observed effect of combined substances being greater than the sum of the individual effects. Additive effects occur when the combined effect is equal to the sum of all individual effects. Antagonistic effects are present when the effect of one or more compounds is less than if they had been used individually [42]. There have been studies that determined that some whole EOs have a greater antibacterial activity than major components mixed, suggesting that minor components are critical to the activity and thus may have synergism $[61,62]$.

Lower levels of EOs and their components can be added to food products when combined with other preservation methods [47]. Some purported synergists of EOs that have been suggested, but not necessarily researched, include: low acidity $/ \mathrm{pH}$, low temperature, mild heat treatments, high hydrostatic pressure (HHP), preservatives (e.g. nitrite and nisin). As $\mathrm{pH}$ decreases, the $\mathrm{EO}$ is able to dissolve the cell membrane of targeted bacteria due to the hydrophobic properties of EOs [51,52,63-70]. Foods that contain high levels of water have been shown to synergistically effect EOs [34].

EOs antibacterial activity is greatly influenced by the atmosphere in which processing occurs. By lowering the amount of oxygen available, it is hypothesized that fewer oxidative changes can take place within the EOs and that anaerobic cells are more sensitive to the action of the EO [71]. Vacuum packing has had a synergistic effect with a variety of EOs $[51,72,73]$. Modified atmosphere packaging (MAP) is known for extending the shelf life of meat and poultry products. When EOs are added to MAP there is an increase in effectiveness when suppressing microbial growth [74,75].

The addition of sodium chloride has been shown to have both synergistic and antagonistic effects on both EOs and their components, depending on the circumstances of addition. In some cases it was shown to have aided in completely preventing growth and production of certain bacteria species, while when added and then placed in other scenarios, sodium chloride was shown to greatly reduce the effectiveness of other EOs and their components [58,27].

The compositional makeup of the food being treated with EOs can be antagonistic when it comes to the effectiveness of the EO to function as an antimicrobial. High fat and protein contents have been shown to protect the bacteria present in foods from the effects of the EO $[76,77,52]$. The physical structure of the food may also contribute factors that limit effectiveness of EO on microbial growth [50].

\section{Safety}

A considerable amount of EOs and their components are classified by the United States Food and Drug Administration (FDA) as generally recognized as safe (GRAS) or have been approved as food additives [5]. Research has indicated that 
some irritation and toxicity can occur from EO exposure. Some EOs that are typically used in the medicinal and aromatherapy fields have been shown to relieve muscle spasms [78-80]. Some examples include: cytotoxicity in gum cells when EOs are added to root canal treatments [23], in vitro cytotoxicity but not in vivo cytotoxicity [81], and contact dermatitis when used frequently $[82,83]$. Since many EOs have not been evaluated completely for their safety properties, it is suggested that before EOs become mainstream and used in higher concentrations, more detailed research should be conducted.

\section{Challenges}

While EOs have been used as flavoring ingredients for years, they still face some challenges for application as antimicrobials in the food industry.

\section{Organoleptics}

Many foods that are generally associated with herbs, spices or seasonings will be the least impacted by the increased use of EOs as antibacterials, due to the current presence of flavors attributed to EOs. However, foods that are generally not formulated using these flavors may be impacted, potentially negatively and positively, depending on the perception of the consumer. Due to the use of EOs as flavor ingredients, it is well understood that EOs have the potential to impart flavors when added to foods. Since there is little research into the organoleptic effects on a variety of foods this is an area that will definitely require further investigation.

\section{Consistency}

[l suggest renaming this section something like "Efficacy", "Uniformity" or "Performance". Consistency is most often used to describe texture or viscosity in foods (e.g. consistometer).

As stated earlier, consistency is often a challenge faced when using EOs [84]. The composition of an individual EO can be affected by a variety of factors including: time of harvest, variety, part of plant used, and method of extraction [5,8587]. In addition to these factors, research has shown that other factors such as: food composition, $\mathrm{pH}$, temperature, and microbial load can all affect the ability of EOs to perform as antimicrobials $[5,65,67,70,88-90]$. Since EOs and their components are highly volatile, there needs to be more research into ways to enhance stability [91].

\section{Resistance}

As with many other antimicrobials it is important to mention there is potential for the bacteria to become resistant to the effects of EOs. It is plausible that combining EOs with current antimicrobials could remedy this resistance, should it occur.

\section{Conclusion}

EOs are widely used as flavoring agents within the food industry. However, use of EOs as antimicrobials is nascent to the industry. There is a great need to continue investigation of EOs role as an antimicrobial. Research has shown a high potential for use of EOs to reduce growth of food pathogens and toxins [10]. As consumer demand for all-natural and clean products increases, EOs may be the best option to improve food safety in these products.

\section{References}

1. Guenther E. Essential Oils. 1st edition. Newyork, NY: Van Norstrand Co; 1948.

2. van de Braak SAAJ, Leijten GCJJ. Essential Oils and Oleoresins: A Survey in the Netherlands and Other Major Markets in the European Union. Rotterdam: CBI: Centre for the Promotion of Imports from Developing Countries; 1999: 116.

3. Fraenkel GS. The Raison d'Etre of Secondary Plant Substances. Science. 1959; 129(3361): 1466-1470. doi: 10.1126/science.129.3361.1466

4. Tajkarimi MM, Ibrahim SA, Cliver DO. Antimicrobial herb and spice compounds in food. Food Control. 2010; 21(9): 1199-1218. doi: 10.1016/j. foodcont.2010.02.003

5. Burt S. Essential oils: their antibacterial properties and potential applications in foods-a review. Int J Food Microbiol. 2004; 94(3): 223-253. doi: 10.1016/j.ijfoodmicro.2004.03.022

6. Deans SG, Ritchie G. Antibacterial properties of plant essential oils. Int J Food Microbiol. 1987; 5(2): 165-180. doi: 10.1016/0168-1605(87)90034-1

7. Oussalah M, Caillet S, Saucier L, Lacroix M. Inhibitory effects of selected plant essential oils on the growth of four pathogenic bacteria: E. coli O157:H7, Salmonella typhimurium, Staphylococcus aureus and Listeria monocytogenes. Food Control. 2007; 18(5): 414-420. doi: 10.1016/j. foodcont.2005.11.009

8. George DR, Smith TJ, Shiel RS, Sparagano OAE, Guy JH. Mode of action and variability in efficacy of plant essential oils showing toxicity against the poultry red mite, Dermanyssus gallinae. Vet Parasitol. 2009; 161(3-4): 276-282. doi: 10.1016/j.vetpar.2009.01.010

9. Enan E. Insecticidal activity of essential oils: octopaminergic sites of action. Comp Biochem Physiol C Toxicol Pharmacol. 2001; 130(3): 325-337. doi: 10.1016/S1532-0456(01)00255-1

10. Kim J, Marshall MR, Wei C. Antibacterial activity of some essential oil components against five foodborne pathogens. J Agric Food Chem. 1995; 43(11): 2839-2845. doi: 10.1021/jf00059a013

11. Astani A, Reichling J, Schnitzler P. Screen for antiviral activities of isolated compounds from essential oils. Evid Based Complement Alternat Med. 2011; 8: 253643. doi: 10.1093/ecam/nep187

12. Fitzgerald DJ, Stratford M, Narbad A. Analysis of the inhibition of food spoilage yeasts by vanillin. Int J Food Microbiol. 2003; 86(1-2): 113-122. doi: 10.1016/S0168-1605(03)00059-X

13. Kalemba D, Kunicka A. Antibacterial and Antifungal Properties of Essential Oils. Curr Med Chem.2003; 10(10):813-829. doi: 10.2174/0929867033457719

14. Silva F, Ferreira S, Duarte A, Mendonça DI, Domingues FC. Antifungal activity of Coriandrum sativum essential oil, its mode of action against Candida species and potential synergism with amphotericin B. Phytomedicine. 2011; 19(1): 42-47. doi: 10.1016/j.phymed.2011.06.033

15. Tserennadmid R, Takó M, Galgóczy L, et al. Anti yeast activities of some essential oils in growth medium, fruit juices and milk. Int J Food Microbiol. 2011; 144(3): 480-486. doi: 10.1016/j.jjfoodmicro.2010.11.004

16. Brenes A, Roura E. Essential oils in poultry nutrition: Main effects and modes of action. Animal Feed Science and Technology. 2010; 158(1-2): 1-14. doi: 10.1016/j.anifeedsci.2010.03.007

17. Ahmadifar E, Falahatkar B, Akrami R. Effects of dietary thymol-carvacrol on growth performance, hematological parameters and tissue composition of juvenile rainbow trout, Oncorhynchus mykiss. J Appl Ichthyol. 2011; 27(4): 1057-1060. doi: 10.1111/j.1439-0426.2011.01763.x

18. Bauer K, Garbe D, Surburg H. Common Fragrance and Flavor Materials: Preparation, Properties, and Uses. 4th edition. Weinheim (WH): WileyVCH; 2001. 
19. 3Crosthwaite D. UK trade within the flavour and fragrance industry. London (LN): IFEAT; 1998.

20. Carson CF, Riley TV. Antimicrobial activity of the essential oil of Melaleuca alternifolia. Lett Appl Microbiol. 1993; 16(2): 49-55. doi: 10.1111/j.1472-765X.1993.tb00340.x

21. van Welie RTH. Dutch Cosmetics Association: Ingredients. 1997

22. Oosterhaven K, Poolman B, Smid EJ. S-carvone as a natural potato sprout inhibiting, fungistatic and bacteristatic compound. Ind Crops Prod. 1995; 4(1): 23-31. doi: 10.1016/0926-6690(95)00007-Y

23. Manabe A, Nakayama S, Sakamoto K. Effects of essential oils on erythrocytes and hepatocytes from rats and dipalmitoyl phosphatidylcholine-liposomes. Jpn J Pharmacol. 1987; 44(1): 77-84. doi: 10.1254/jjp.44.77

24. Cox S D, Mann CM, Markham JL, et al. The mode of antimicrobial action of the essential oil of Melaleuca alternifolia (tea tree oil). J Appl Microbiol. 2001; 88(1): 170-175. doi: 10.1046/j.1365-2672.2000.00943.x

25. van Krimpen MM, Binnendijk GP. Ropadiar as alternative for antimicrobial growth promoter in diets or weanlings pigs. Report Experimental Station for Cattle Husbandry, Sheep Herd and Horse Hitchery. 2001.

26. Ilsley $\mathrm{S}$, Miller $\mathrm{H}$, Greathead $\mathrm{H}$, Kamel $\mathrm{C}$. Herbal sow diets boost preweaning growth. Pig Progress. 2002; 18(4): 8-10.

27. Moleyar V, Narasimham P. Antibacterial activity of essential oil components. Int J Food Microbiol. 1992; 16(4): 337-342. doi: 10.1016/01681605(92)90035-2

28. Packiyasothy EV, Kyle S. Antimicrobial Properties of Some Herb Essential Oils. Food Australia. 2002; 54(9): 384-387

29. Senatore F. Influence of Harvesting Time on Yield and Composition of the Essential Oil of a Thyme (Thymus pulegioides L.) growing Wild in Campania (Southern Italy). J Agric Food Chem. 1996; 44(5):1327-1332. doi: 10.1021/ jf950508z

30. Russo M, Galletti GC, Bocchini P, Carnacini A. Essential Oil Chemical Composition of Wild Populations of Italian Oregano Spice (Origanum vulgare ssp. hirtum (Link) letswaart): A Preliminary Evaluation of their use in Chemotaxonomy by Cluster Analysis. 1. Inflorescences. J Agric Food Chem. 1998; 46(9): 3741-3746. doi: 10.1021/jf980087w

31. Arras G, Grella GE. Wild thyme, Thymus capitatus, essential oil seasonal changes and antimycotic activity. J Hortic Sci Biotechnol. 1992; 67(2): 197202.

32. Marotti M, Piccaglia R, Giovanelli E, Deans SG, Eaglesham E. Effects of planting time and mineral fertilization on peppermint (mentha $x$ piperita I.) essential oil composition and its biological activity. Flavour Fragr J. 1994; 9(3):125-129. doi: 10.1002/ffj.2730090307

33. Delaquis PJ, Stanich K, Girard B, Mazza G. Antimicrobial activity of individual and mixed fractions of dill, cilantro, coriander and eucalyptus essential oils. Int J Food Microbiol. 2002; 74(1-2): 101-109. doi: 10.1016/ S0168-1605(01)00734-6

34. Shelef LA. Antimicrobial effects of spices. J Food Saf. 1984; 6(1): 29-44. doi: 10.1111/j.1745-4565.1984.tb00477.x

35. Farag RS, Daw ZY, Hewedi FM, El-Baroty GSA. Antimicrobial Activity of Some Egyptian Spice Essential Oils. J Food Prot. 1989; 52(9): 665-667. doi: 10.4315/0362-028X-52.9.665

36. Ultee A, Smid E. Influence of carvacrol on growth and toxin production by Bacillus cereus. Int J Food Microbiol. 2001; 64(3): 373-378. doi: 10.1016/ S0168-1605(00)00480-3

37. Knobloch $\mathrm{K}$, Weigand $\mathrm{H}$, Weis $\mathrm{N}$, et al. Action of terpenoids on energy metabolism. Progress in Essential Oil Research: 16th International Symposium on Essential Oils. 1986; 429-445.

38. Sikkema J, de Bont JA, Poolman B. Interactions of cyclic hydrocarbons with biological membranes. J Biol Chem. 1994; 269: 8022-8028.

39. Dorman HJD, Deans SG. Antimicrobial agents from plants: antibacterial activity of plant volatile oils. J Appl Microbiol. 2008; 88(2): 308-316. doi: 10.1046/j.1365-2672.2000.00969.x
40. Ultee A, Bennik MHJ, Moezelaar R. The Phenolic Hydroxyl Group of Carvacrol Is Essential for Action against the Food-Borne Pathogen Bacillus cereus. Appl Environ Microbiol. 2002; 68(4): 1561-1568. doi: 10.1128/ AEM.68.4.1561-1568.2002

41. Solomakos N, Govaris A, Koidis P, Botsoglou N. The antimicrobial effect of thyme essential oil, nisin, and their combination against Listeria monocytogenes in minced beef during refrigerated storage. Food Microbiol. 2008; 25(1): 120-127. doi: 10.1016/j.fm.2007.07.002

42. Davidson PM, Parish ME. Methods for testing the efficacy of food antimicrobials. Food Technol. 1989; 43: 148-155.

43. Russell N, Gould GW. Food Preservatives. Food Sci Nutr. 1991; 348-370.

44. Smid EJ, Dekker M. Natural Antimicrobials for Food Preservation. 1st edition. New York (NY): Marcel Dekker Inc; 1991.

45. Skandamis PN, Nychas GJE. Development and Evaluation of a Model Predicting the Survival of Escherichia coli O157: H7 NCTC 12900 in Homemade Eggplant Salad at various Temperatures, $\mathrm{pHs}$ and Oregano Essential Oil Concentrations. Appl Environ Microbiol. 2000; 66(4): 1646 1653. doi: 10.1128/AEM.66.4.1646-1653.2000

46. Tipsrisukond N, Fernando LN, Clarke AD. Antioxidant Effects of Essential Oil and Oleoresin of Black Pepper from Supercritical Carbon Dioxide Extractions in Ground Pork. J Agric Food Chem. 1998; 46(10): 4329-4333. doi: 10.1021/jf9802880

47. Jayasena DD, Jo C. Essential oils as potential antimicrobial agents in meat and meat products: A review. Trends Food Sci Technol. 2013; 34(2): 96-108. doi: 10.1016/j.tifs.2013.09.002

48. Goulas $A E$, Kontominas MG. Combined effect of light salting, modified atmosphere packaging and oregano essential oil on the shelf-life of sea bream (Sparus aurata): Biochemical and sensory attributes. Food Chem 2007; 100(1): 287-296. doi: 10.1016/j.foodchem.2005.09.045

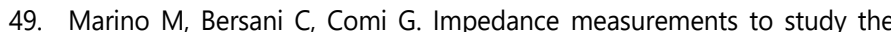
antimicrobial activity of essential oils from Lamiaceae and Compositae. Int J Food Microbiol. 2001; 67(3): 187-195. doi: 10.1016/S0168-1605(01)004470

50. Skandamis PN, Nychas GJE. Effect of oregano essential oil on microbiological and physico-chemical attributes of minced meat stored in air and modified atmospheres. J Appl Microbiol. 2002; 91(6): 1011-1022. doi: 10.1046/j.1365-2672.2001.01467.x

51. Tsigarida E, Skandamis P, Nychas GJE. Behaviour of Listeria monocytogenes and autochthonous flora on meat stored under aerobic, vacuum and modified atmosphere packaging conditions with or without the presence of oregano essential oil at $5^{\circ} \mathrm{C}$. J Appl Microbiol. 2001; 89(6): 901-909. doi: 10.1046/j.1365-2672.2000.01170.x

52. Tassou CC, Drosinos EH, Nychas GJE. Effects of essential oil from mint (Mentha piperita) on Salmonella enteritidis and Listeria monocytogenes in model food systems at $4^{\circ}$ and $10^{\circ} \mathrm{C}$. J Appl Bacteriol. 1995; 78(6): 593-600. doi: 10.1111/j.1365-2672.1995.tb03104.x

53. Koutsoumanis K, Lambropoulou K, Nychas GJE. A predictive model for the non-thermal inactivation of Salmonella enteritidis in a food model system supplemented with a natural antimicrobial. Int J Food Microbiol. 1999; 49(1-2): 63-74. doi: 10.1016/S0168-1605(99)00054-9

54. Ouattara B, Sabato SF, Lacroix M. Combined effect of antimicrobial coating and gamma irradiation on shelf life extension of pre-cooked shrimp (Penaeus spp.). Int J Food Microbiol. 2001; 68(1): 1-9. doi: 10.1016/ S0168-1605(01)00436-6

55. Harpaz S, Glatman L, Drabkin V, Gelman A. Effects of herbal essential oils used to extend the shelf life of freshwater-reared Asian sea bass fish (Lates calcarifer). J Food Prot. 2003; 66(3): 410-417.

56. Bayoumi S. Bacteriostatic effect of some spices and their utilization in the manufacture of yogurt. Chemistry, Microbiology, Technology of Food. 1992; 14(1-2): 21.

57. Smith-Palmer A, Stewart J, Fyfe L. The potential application of plant essential oils as natural food preservatives in soft cheese. Food Microbiol. 2001; 18(4): 463-470. doi: 10.1006/fmic.2001.0415 
58. Ultee A, Slump RA, Steging G, Smid EJ. Antimicrobial activity of carvacrol toward Bacillus cereus on rice. J Food Prot. 2000; 63(5): 620-624.

59. Soultos N, Tzikas Z, Christaki E, Papageorgiou K, Steris V. The effect of dietary oregano essential oil on microbial growth of rabbit carcasses during refrigerated storage. Meat Sci. 2009; 81(3): 474-478. doi: 10.1016/j. meatsci.2008.10.001

60. Govaris A, Botsoglou E, Florou-Paneri P, Moulas A, Papageorgiou G. Dietary supplementation of oregano essential oil and a-tocopheryl acetate on microbial growth and lipid oxidation of turkey breast fillets during storage. Int J Poult Sci. 2005; 4(12): 969-975. doi: 10.3923/ijps.2005.969.975

61. Gill AO, Delaquis $P$, Russo $P$, Holley RA. Evaluation of antilisterial action of cilantro oil on vacuum packed ham. Int J Food Microbiol. 2002; 73(1): 8392. doi: 10.1016/S0168-1605(01)00712-7

62. Mourey A, Canillac N. Anti-Listeria monocytogenes activity of essential oils components of conifers. Food Control. 2002; 13(4-5): 289-292. doi: 10.1016/S0956-7135(02)00026-9

63. Al-Reza SM, Rahman A, Lee J, Kang SC. Potential roles of essential oil and organic extracts of Zizyphus jujuba in inhibiting food-borne pathogens. Food Chem. 2010; 119(3): 981-986. doi: 10.1016/j.foodchem.2009.07.059

64. Tassou C, Drosinos E, Nychas GJE. Inhibition of resident microbial flora and pathogen inocula on cold fresh fish fillets in olive oil, oregano and lemon juice under modified atmosphere or air. J Food Prot. 1996; 59(1): 31-34.

65. Gould GW. Industry perspectives on the use of natural antimicrobials and inhibitors for food applications. J Food Prot. 1996; 59(13): 82-86. doi: 10.4315/0362-028X-59.13.82

66. Marino M, Bersani C, Comi G. Antimicrobial activity of the essential oils of Thymus vulgaris L. measured using a bioimpedometric method. J Food Prot. 1999; 62(9): 1017-1023.

67. Karatzas AK, Bennik MHJ, Smid EJ, Kets EPW. Combined action of Scarvone and mild heat treatment on Listeria monocytogenes Scott A. J ApplMicrobiol.2001;89(2):296-301.doi:10.1046/j.1365-2672.2000.01110.x

68. Devlieghere F, Vermeiren L, Debevere J. New preservation technologies: Possibilities and limitations. Int Dairy J. 2004; 14(4): 273-285. doi: 10.1016/j. idairyj.2003.07.002

69. Zhou GH, Xu XL, Liu Y. Preservation technologies for fresh meat-A review. Meat Sci. 2010; 86(1): 119-128. doi: 10.1016/j.meatsci.2010.04.033

70. Juven BJ, Kanner J, Sched F, Weisslowicz H. Factors that interact with the antibacterial action of thyme essential oil and its active constituents. $J$ Appl Bacteriol. 1994; 76(6): 626-631.

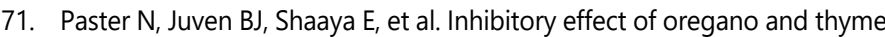
essential oils on moulds and foodborne bacteria. Lett Appl Microbiol. 1990; 11(1): 33-37. doi: 10.1111/j.1472-765X.1990.tb00130.x

72. .Stecchini ML, Sarais I, Giavedoni P. Effect of Essential Oils on Aeromonas hydrophila in a Culture Medium and in Cooked Pork. J Food Prot. 1993; 56(5): 406-409. doi: 10.4315/0362-028X-56.5.406

73. Viuda-Martos M, Ruiz-Navajas Y, Fernández-López J, Pérez-Álvarez JA Effect of added citrus fibre and spice essential oils on quality characteristics and shelf-life of mortadella. Meat Sci. 2010; 85(3): 568-576. doi: 10.1016/j. meatsci.2010.03.007

74. Karabagias I, Badeka A, Kontominas MG. Shelf life extension of lamb meat using thyme or oregano essential oils and modified atmosphere packaging. Meat Sci. 2011; 88(1): 109-116. doi: 10.1016/j.meatsci.2010.12.010

75. Pandit VA, Shelef LA. Sensitivity of Listeria monocytogenes to rosemary (Rosmarinus officinalis L.). Food Microbiol. 1994; 11(1): 57-63. doi: 10.1006/ fmic.1994.1008
76. Hasapidou A, Savvaidis IN. The effects of modified atmosphere packaging EDTA and oregano oil on the quality of chicken liver meat. Int Food Res. 2011; 44(9): 2751-2756. doi: 10.1016/j.foodres.2011.06.011

77. Aureli P, Costanini A, Zolea S. Antimicrobial activity of some plant essential oils against Listeria monocytogenes. J Food Prot. 1992; 55(5): 344-348. doi: 10.4315/0362-028X-55.5.344

78. Lis-Balchin M, Hart S, Deans SG, Eaglesham E. Comparison of the pharmacological and antimicrobial action of commercial plant essential oils. J Herbs Spices Med Plants. 1995; 4(2): 69-86. doi: 10.1300/J044v04n02_11

79. Madeira SVF, Matos FJA, Leal-Cardoso JH, Criddle DN. Relaxant effects of the essential oil of Ocimum gratissimum on isolated ileum of the guinea pig. $J$ Ethnopharmacol. 2002; 81(1): 1-4. doi: 10.1016/S0378-8741(02)00049-1

80. Lis-Balchin M, Ochocka R, Deans SG, Hart S, Asztemborska M. Differences in bioactivity between the enantiomers of $\alpha$-pinene. Journal of Essential Oil Research. 1999; 11(3): 393-397. doi: 10.1080/10412905.1999.9701162

81. Stammati A, Bonsi P, Zucco F, Moezelaar R, Alakomi HL, von Wright A Toxicity of Selected Plant Volatiles in Microbial and Mammalian Shortterm Assays. Food Chem Toxicol. 1999; 37(8): 813-823. doi: 10.1016/ S0278-6915(99)00075-7

82. Carson CF, Riley TV. Safety, efficacy and provenance of tea tree (Melaleuca alternifolia) oil. Contact Dermatitis. 2001; 45(2): 65-70. doi: 10.1034/j.1600-0536.2001.045002065.x

83. Bleasel N, Tate B, Rademaker M. Allergic contact dermatitis following exposure to essential oils. Australas J Dermatol. 2002; 43(3): 211-213. doi: 10.1046/j.1440-0960.2002.00598.x

84. Fasseas MK, Mountzouris KC, Tarantilis PA, Polissiou M, Zervas G. Antioxidant activity in meat treated with oregano and sage essential oils. Food Chem. 2008; 106(3): 1188-1194. doi: 10.1016/j.foodchem.2007.07.060

85. Badi HN, Yazdani D, Ali SM, Nazari F. Effects of spacing and harvesting time on herbage yield and quality/quantity of oil in thyme, Thymus vulgaris L. Ind Crops Prod. 2004; 19(3): 231-236. doi: 10.1016/j. indcrop.2003.10.005

86. Ložien K, Vaičiūnien J, Venskutonis PR. Chemical composition of the essential oil of different varieties of thyme (Thymus pulegioides) growing wild in Lithuania. Biochem Syst Ecol. 2003; 31(3): 249-259. doi: 10.1016/ S0305-1978(02)00142-4

87. Hyldgaard M, Mygind T, Meyer RL. Essential Oils in Food Preservation: Mode of Action, Synergies, and Interactions with Food Matrix Components. Front Microbiol. 2012; 3. doi: 10.3389/fmicb.2012.00012

88. Busatta C, Vidal RS, Popiolski AS, et al. Application of Origanum majorana L. essential oil as an antimicrobial agent in sausage. Food Microbiol. 2008; 25(1): 207-211. doi: 10.1016/j.fm.2007.07.003

89. Rattanachaikunsopon P, Phumkhachorn P. Potential of Coriander (Coriandrum sativum) Oil as a Natural Antimicrobial Compound in Controlling Campylobacter jejuni in Raw Meat. Biosci Biotechnol Biochem. 2010; 74(1): 31-35. doi: 10.1271/bbb.90409

90. Somolinos M, García D, Condón S, Mackey B, Pagán R. Inactivation of Escherichia coli by citral. J Appl Microbiol. 2010; 108(6): 1928-1939. doi: 10.1111/j.1365-2672.2009.04597.x

91. Friedman M, Kozukue N, Harden LA. Cinnamaldehyde Content in Foods Determined by Gas Chromatography-Mass Spectrometry. J Agric Food Chem. 2000; 48(11): 5702-5709. doi: 10.1021/jf000585g 